\title{
Empowering Peer Examination Technique in Assessing Students' \\ Speaking Skill
}

\begin{abstract}
This paper portrays peer examination execution in showing talking aptitude in Senior High School understudies. The assessment was arranged as edifying examination in which the examiner filled in as a working observer. The investigation individuals in this assessment were the essential year understudies and a teacher who applied partner examination strategy in the senior optional school in Cilegon. The investigator applied a subsequent collaboration technique by seeing the homeroom using discernment sheet, and taking field notes to see the pattern of execution of companion assessment. In looking at the data, the expert used data decline, data show, and affirmation. The execution association of partner examination was showed up by the investigation lobby discernment in three phases; preexecution of companion assessment, during peer examination, and post companion assessment. The expert moreover found that the productive execution of partner assessment was a consequence of the instructor's emphasis on offering score to the companions and raising the understudies' motivation to coordinate buddy examination, making them sure to play out the friend evaluation measure.
\end{abstract}

Keywords: peer examination, speaking skill

Talking gets one of the essential perspectives for the EFL understudies in learning English as an unknown dialect. Through talking, the understudies can do vis-à-vis correspondence and understand about the discussion. Additionally, it empowers them to pass on their considerations, information, encounters, and thoughts in the verbally expressed structure. For example, the understudies complete a little conversation during the instructing and learning measure, advise their exercises to their companions and others. Moreover, Sharma (2018) expressed that talking is likewise used to communicate feeling, realities, just as sentiments precipitously when the understudy conveys to other people. Thusly, talking is should have been grown particularly by the understudies in senior secondary school level.

To discover the understudies' advancement about their talking ability, it needs a fitting method to survey their talking exercises. This current examination elevates peer evaluation to be applied to the senior high 
understudies in acquiring English-talking ability. Friend evaluation is expected to notice the understudies' capacity of talking expertise through giving useful remarks, recoding their inputs, and fostering understudies' mindfulness about their talking capacity. The execution of a companion appraisal can be a chance for the understudies to turn into a functioning student in the homeroom. Through the companion criticism, they will offer a rectification and contribution to their companions and furthermore share their thoughts as the improvement of the learning cycle. Besides, it could be used as the learning device for the understudies and accomplish the social work on including local area, support, collections, and reification. In agreement to the significance of friend appraisal, the essayist implies that the understudies' point of view identified with its execution is as yet should have been investigated. Moreover, the greater part of the past investigates underline on the composing ability, though this examination is zeroing in on the talking expertise. Hence, it is as yet intriguing through the inside and out examination.

In view of the focal point of the exploration, investigates about peer evaluation have been directed by a few researchers with alternate points of view. For example, Wang (2016) appears to show that peer appraisal advances the understudies' capability in English composing ability. In view of his examination, the author gives a few rules during the execution of friend evaluation, like substance, sentence structure, vocabularies, feeling, articulation, sayings and others. At that point, the educators can screen the understudies' advancement from peer evaluation that has been surveyed by different understudies. Another past research is done by Astuti (2013) which inspected the impact of friend evaluation in improving scholarly understudies. It implies that it has improved the nature of understudies composing altogether. Another connected investigation is an exploration entitled The Effect of Peer Assessment on Writing Anxiety in Turkish EFL Learners which led by Yastibas and Yastibas (2015), it showed that peer appraisal could diminish the understudies' nervousness, increment their 
certain, and improve their composing capacity through cooperation to one another.

In agreement to the past investigations, indicate can't help thinking that the friend appraisal can be used to evaluate the talking expertise on different levels and the majority of the explores are prevail to give the positive effect on the understudies in the wake of acquiring the evaluation. Thusly, to indicate this exploration, the authors center around researching the understudies' discernment on peer evaluation especially on the senior secondary school understudies. Also, the point of this exploration is investigating the understudies' impression of companion evaluation towards talking ability. The information will be administrated through unmistakable subjective examination.

This examination was directed engagingly in which the scientist filled in as a functioning eyewitness in gathering the information. It implies that the scientist came into one of the classes in senior secondary school of Methodist Banda Aceh to notice the execution of friend evaluation in talking expertise. Subjective strategy is trailed by a portrayal of homeroom practices, arrangement of cycles, and more abstract deductions toward speculation. The overall objective of subjective methodology is to give rich, clear information about what occurs in the second language homeroom.

To get information assortment on the field, the analyst utilized two instruments. They were perception sheet and field note. Perception was vital to acquire fundamental information for this examination where the specialist noticed the execution of friend evaluation in talking ability in the class. The scientist utilized perception sheet to help the analyst following the movement in the study hall. The scientist as a non-member eyewitness went to the class noticing the execution of companion appraisal in the class by recording and taking notes. The scientist noticed each and every things in three stages of perception; pre execution of friend evaluation, during peer appraisal, and post execution of companion appraisal. The specialist didn't include in any exercises in the study hall since it was accepted to digress the objectivity of companion appraisal. 
The analyst likewise took notes about the fascinating exercises, place, date, time, and strange developments in the class. The field note was likewise used to note about understudies' seat course of action, questions, truancy, and the entirety of the startling things that occurred in the homeroom. This information assortment assisted the analyst with sorting out the execution of friend appraisal.

Information investigation was directed during the examination for addressing research issue. In this part the essayist received the system created by Miles and Huberman (1994, p. 36) to depict the significant periods of information investigation; information decrease, information show, and check. Data reduction refers to the process of collecting the mass of information that the researcher may obtain during the study which can be reduced and organized. The raw data was reduced for choosing the main data, focusing on important ones, and searching for the concepts and model by reviewing the result of observation and reading the questionnaire findings.

Information show is coordinated and compacted data that has been diminished and can be shown as a content, outline, diagram, or table that gives another method of the information (Miles \&Huberman, 1994, p. 38). In this stage, the information of this investigation that had been diminished was shown by the scientist. This interaction permitted the author to finish up the examination and found solutions for the exploration issues.

Confirmation is the inside and out appraisal stage for getting ends. After all the survey results were arranged, it made analyst simpler to reach inferences to respond to the examination questions. The analyst reached determinations on the impression of understudies toward peer evaluation through poll examined.

Friend appraisal was successfully completed in senior auxiliary school in Cilegon because of the instructor gave an undeniable explanation about the significance of partner assessment, its techniques and its benefits to the understudies. The teacher in like manner settled trust among understudies to create trust while doing the evaluation. A sensible 
explanation about doing this examination made the friend assessment compelling.

Companion evaluation can be done in the homeroom adequately with a sensible explanation from the teacher. The instructor moreover didn't have to worry about the result of companion appraisal peer assessment execution was revolved more around the cycle than on the possible result. The way wherein the instructor did the pre-done friend assessment, during peer examination, and post-executed of buddy assessment was a critical factor in peer assessment execution. The teacher could set up trust among understudies. A remarkable execution of partner assessment in first year of Methodist class was a direct result of the less relationship of the understudies in choosing the rubric score. If there are educators who need to execute peer assessment in their homeroom, they can remember understudies for choosing score of the rubric by discussing what centers need and need not be overviewed in the talking execution. 


\section{REFERENCES}

Albana, H. H., Marzuki, A. G., Alek, A., \& Hidayat, D. N. (2020). Cohesive Devices in Student's Writing (A Discourse Analysis on Argumentative Text). Jurnal Pendidikan Humaniora, 8(1), 6-11.

Alek, A., Marzuki, A. G., Farkhan, M., \& Deni, R. (2020). Self-Assessment in Exploring EFL Young learners' Speaking Skill. Al-Ta lim Journal, 27(2), 208-214.

Alek, A., Marzuki, A. G., Farkhan, M., Surahman, D., Daryanto, D., \& Febrianto, S. (2020). Computer Based Testing in Senior High School on National Examination. Indonesian Journal of Learning Education and Counseling, 2(2), 204-210.

Angeles: University of California.

Brown, D. H. (2004). Language Assessment: Principles and Classroom Chan, C. (2010). Assessment: Self and Peer Assessment, Assessment

Falchikov, N. (1995). Peer feedback marking: Developing peer assessment. Innovations in Education and training International, 32(2), 175-187.

Fatimah, A. S., Santiana, S., \& Saputra, Y. (2019). Digital Comic: An Innovation of Using Toondoo As Media Technology for Teaching English Short Story. English Review: Journal of English Education, 7(2), 101-108.

Hansen, J.A., Andree. M. 2019. Using and Rejecting Peer Feedback in the Science Classroom: A Study of Students' Negotiation on How to Use Peer Feedback when Designing Experiments. Research in Science \&Technological Education. 1-20.

Herman, J. L. (1992). A Practical Guide to Alternative Assessment. Los

Kaufman, J. H., \& Schunn, C. D. (2010). Students' Perception about Peer Assessment for Writing: Their origin and Impact on Revision Work. Journal of Science \& Business, DOI 10.1007/s11251-010-9133-6.

Khotimah, S. (2014). THE USE OF PROBLEM BASED LEARNING TO IMPROVE STUDENTS'SPEAKING ABILITY. In ELT Forum: Journal of English Language Teaching (Vol. 3, No. 1).

Kuliahana, A., \& Marzuki, A. G. (2020). Repetition Technique in an EFL Speaking Class in Islamic Higher Education in Indonesia. Academic Journal Perspective: Education, Language, and Literature, 8(1), 2028.

L. Andrade, \& G. J. Cizek (Eds.), Handbook of Formative Assessment (pp. 69-75). New York, NY: Routledge.

Lam K.W. \& Hassan A. \& Sulaiman T. \& Kamarudin N. (2018). Evaluating the Face and Content Validity of an Instructional Technology Competency Instrument for University Lecturers in Malaysia. International Journal of Academic Research in Business and Social Sciences. 8(5). 367-385.

Leong, L.M, \& Ahmadi, S.M. (2017). An Analysis of Factors Influencing Learners' English-Speaking Skill. International Journal of Research in English Education, 34-41. 
Lin, C. J. (2019). An online peer assessment approach to supporting mindmapping flipped learning activities for college English writing courses. Journal of Computers in Education, 6(3), 385-415.

Mansourzadeh, N. (2014). A comparative study of teaching vocabulary through pictures and audio-visual aids to young Iranian EFL learners. Journal of Elementary Education, 24(1), 47-59.

Marzuki, A. G. (2019). The Implementation of SQ3R Method to Develop Learners' Reading Skill on Islamic Texts in EFL Class in Indonesia. Register Journal, 12(1), 49-61.

Marzuki, A. G. (2019). The Roles of School Principal Leadership in Developing English Teachers' Creativities in Palu. Al-Ta lim Journal, 26(3), 267-279.

Marzuki, A. G. (2019). Utilizing Recorded English Dialogues in Teaching English Word Stress to Islamic Higher Education Learners in Indonesia. Jurnal Pendidikan Islam, 5(1), 53-64.

Marzuki, A. G., Alim, N., \& Wekke, I. S. (2018). Improving the reading comprehension through cognitive reading strategies in language class of coastal area in indonesia. In IOP Conference Series: Earth and Environmental Science, 156(1), 012050). IOP Publishing.

Marzuki, A.G. (2016). Utilizing cooperative learning in islamic college learners' classroom. IJEE (Indonesian Journal of English Education), 3(2), 123-139.

Marzuki, A.G. (2017). Applying mind mapping technique in improving english vocabulary mastery in an efl classroom. Paedagogia: Jurnal Pendidikan, 6(2), 276-293.

Marzuki, A.G. (2017). Utilizing pictures in increasing learners' vocabulary mastery in an efl class in palu city indonesia. Musawa: Journal for Gender Studies, 9(2), 191-233.

Musfirah, Y. (2019). The Use of Peer Assessment in Speaking Skill. English Education Journal, 10(1), 67-79. Practices. New York: Longman.

Resources. Journal of University of Hong Kong.

Santiana, S., \& Fatimah, A. S. (2017). Prezi, Cloud-Based Presentation, for Teaching: How is it Interesting?. EduLite: Journal of English Education, Literature and Culture, 2(2), 445-456.

Strijbos, J. W., \& Sluijsmans, D. (2010).Unravelling Peer Assessment: Methodological, Functional, and Conceptual Developments. Learning and Instruction, 20(4), 265-269.

Topping, K. J. (2010).Peers as a Source of Formative Assessment. In: H. 
